\title{
The Contestation of Islamic and Nationalists Parties in 2019 Election
}

\author{
Hasse Jubba, ${ }^{1}$ Zuly Qodir, ${ }^{2}$ Irwan Abdullah, ${ }^{3}$ Saifuddin Zuhri Qudsy, ${ }^{4}$ Mega Hidayati, ${ }^{5}$ \\ Mustaqim Pabbajah, ${ }^{6}$ Rabiatul Adawiah, ${ }^{7}$ Suparto Iribaram, ${ }^{8}$ Misran ${ }^{9}$ \\ \{hasse@umy.ac.id ${ }^{1}$, zuly_qodir@yahoo.com², irwanabdullah9@gmail.com ${ }^{3}$, saifuddin.zuhri@uin- \\ suka.ac.id ${ }^{4}$, mega.hidayati@umy.ac.id ${ }^{5}$, mustaqim_pabbajah@uty.ac.id ${ }^{6}$, rabiatul.a@mail.ugm.ac.id ${ }^{7}$, \\ damiribar@yahoo.co.id $\bar{d}^{8}$, misran@umy.ac.id $\left.{ }^{9}\right\}$ \\ Islamic Politics, Universitas Muhammadiyah Yogyakarta ${ }^{1}$, Islamic Politics, Universitas \\ Muhammadiyah Yogyakarta ${ }^{2}$, Universitas Gadjah Mada \& IA Scholar Foundation ${ }^{3}$, UIN \\ Sunan Kalijaga Yogyakarta \& IA Scholar Foundation ${ }^{4}$, Islamic Politics, Universitas \\ Muhammadiyah Yogyakarta ${ }^{5}$, Universitas Teknologi Yogyakarta \& IA Scholar Foundation ${ }^{6}$, \\ Universitas Gadjah Mada \& IA Scholar Foundation ${ }^{7}$, IAIN Fattahul Muluk Jayapura ${ }^{8}$, Islamic \\ Politics, Universitas Muhammadiyah Yogyakarta ${ }^{9}$
}

\begin{abstract}
The 2019 elections continue the contestation between Islamic political and nationalist parties in Indonesia. The contestation of these two-party groups had occurred since 1955 when the first general election was held. This article discusses the forms of contestation between the two political parties groups in the 2019 election. The literature obtained from a comprehensive search of articles and books faces competition between the two political groups. This article found that the two-party groups tried to reach the public by conducting out various political activities such as recruitment of religious leaders, empowerment of religious institutions, and the establishment of political wing organizations. This article states that the political activities attached the contestation of the two parties by involving "religion" are the strategy of majority election, in this case, Muslims.
\end{abstract}

Keywords: Contestation; Islamic Political Party; Nationalist Political Party; Majority Voter; Election

\section{Introduction}

The 2019 general election is an event to show the continued defeat of Islamic political parties in Indonesia. The first defeat of Islamic political parties occurred in the 1955. Up to 2019, election in Indonesia have been held 11 times, it means that many Islamic political parties have experienced defeats, and were quite good only in the first general election, 1955. Of the contestant parties, the top five were occupied by the Indonesian National Party/PNI (22.32\% of the vote or 57 seats), Masyumi (20.92\% of the vote or 57 seats), Nahdlatul Ulama/NU (18.41\% of the vote or 45 seats), the Indonesian Communist Party/PKI (16.36\% of the vote or 39 seats), and the Indonesian Islamic Syarikat Party (2.89\% of the vote or eight seats) of the total votes of $37,785,299$ or 257 parliamentary seats at that time. Looking at the 
votes obtained by Islamic political parties (Masyumi, NU, and PSII), it was quite significant, namely $42.22 \%$ of the vote with 110 seats, while the combined nationalist parties won $46.80 \%$ of the vote.

In the 1971 election during the New Order era, ten contestants participated, and only eight political parties won seats in parliament. The Nahdlatul Ulama Party won $27.12 \%$ of the vote (58 seats), the Indonesian Muslim Party won $5.36 \%$ of the vote (24 seats), the Indonesian Islamic Syarikat Party won $2.39 \%$ of the vote (10 seats). The Islamic Education Movement won $0,69 \%$ of the vote ( 2 seats). These four Islamic political parties only won $27.12 \%$ of the vote or 94 seats from the accumulated votes. Meanwhile, the nationalist parties won $72.88 \%$ of the vote or 226 seats. The Golkar Party won the majority vote with $62.8 \%$ (236 seats), followed by the Indonesian National Party, which won $6.93 \%$ of the vote or 20 seats in parliament. In the 1997 election or the last election of the New Order, only three political parties participated (the United Development Party/PPP, Golkar Party, and the Indonesian Democratic Party/PDI). In the election, Golkar won a majority again $(74.51 \%)$ of votes, followed by PPP (22.43\%) and PDI (3.06\%) votes.

In the 1999 election, which 48 contestants attended, the Indonesian Democratic Party of Struggle (PDI-P) became the political party that won the most votes (33.74\%), followed by the Golkar Party (22.44\%), the National Awakening Party/PKB won $12.61 \%$ voice. The PPP won $10.71 \%$ of the vote, and the National Mandate Party (PAN) won $7.12 \%$. It appears that the nationalist parties (PDI-P and Golkar) gained $56.18 \%$ of the vote, while the Islamic political parties (PKB, PPP, and PAN) received $29.44 \%$ of the vote. In the 2019 election, the combined Islamic parties PKS, PKB, PAN, PPP, and PBB only received a slight increase in votes with an increase of $30.05 \%$ or 171 seats, while the nationalist parties PDIP, Gerindra, Golkar, Nasdem, and Democrats won $610.03 \%$ of the vote or 404 seats. The PBB cannot meet the $4 \%$ threshold or the parliamentary threshold of valid votes so it does not get a seat in parliament.

Many experts have done research on the condition of Islamic parties in Indonesia. At least, there are three trends regarding the Islamic party condition. First, the internal conflicts of Islamic political parties, such as a study conducted by (Nurdin et al., 2019, saw the internal conflicts of Islamic parties, especially PKS and PPP. Likewise,Sumarno (2015) saw how NU got out of Masyumi, which had a relationship between 1945-1960. Then, this condition has been laid a new Islamic party that received broad support from social and youth organizations, even retired military/police officers. Second, the change in the orientation of the Islamic party (Herdiansah, 2017) saw that the Islamic party had shifted to a more pragmatic direction and abandoned its ideology, hence the Islamic based was increasingly blurred. Thus, the orientation of Islamic parties is more towards power than the struggle to meet the aspirations of Muslim voters (Kadir, 2014). Third, studies that look at the involvement of religious leaders in political parties aim that there is a "moral" touch in politics (Royyani \& Takayasa, 2020).

Political parties among experts are organized groups whose members have the same orientation, values, and ideals to achieve power. Meanwhile, the Islamic political parties becomes the core of this article that make Islam not only the basis of the party but also as the basis of the struggle. In this case, the standard of Islamic politics is in the essence and principles, not in the political system and form.

Islamic parties are parties that use Islam as an ideology or party organization principle which is expressly stated in the party's Articles of Association and Bylaws (AD/ART). Meanwhile, Islamic political parties are parties that use Islamic symbols as their "political identity"'. However, it is not explicitly stated in the AD/ART, but these parties from the 
history of establishment and political practice cannot be separated from Islam. As political identities and symbols (Nurhasim, 2016).

Some of the parties included in the first group are the United Development Party (PPP) and the Prosperous Justice Party (PKS), while the second group is PKB and PAN. Chapter II Article 1 mentions that "PPP is based on Islam, characterized by Ahlussunnah Wal Jama'ah." Meanwhile, in the AD/ART PKS Chapter, I Article 2, "Parties based on Islam." As for PKB since its birth, it cannot be separated from Nahdlatul Ulama (NU), as well as PAN, which has always been identified with Muhammadiyah because these two parties have a relatively strong relationship with these Islamic organizations (Nashir et al., 2019; Qodir et al., 2021). These two parties did not explicitly mention Islam as their ideology, but the development of both cannot be separated from Islamic symbols. Bezhan (2017) mentions that the purpose of forming an Islamic political party is to spread their ideas and compete with nationalist democratic political parties.

Apart from Islamic political parties contestant, there are also non-religious political parties, which are called nationalist political parties. This term is only to facilitate the definition and provide "opponents" of the political parties with an Islamic pattern. Nationalist political parties can be said that do not make religion as the principle of their party. This can be seen in the AD/ART. In AD/ART Chapter II Article 1 of the Indonesian Democratic Party of Struggle (PDIP), for example, it is stated that "The party is based on Pancasila as stated in the Preamble to the 1945 Constitution of the Republic of Indonesia with the soul and spirit of its birth on June 1, 1945". Likewise, for the Golkar Party (Golkar), in Chapter III Article 5, it is stated that "the GOLKAR Party is based on Pancasila." These two parties used Pancasila as the party principle so that both parties were placed as a nationalist style, such as the Gerindra, Nasdem, and Democrat parties. This article is based on the assumption that the defeat of Islamic political parties was caused by uniform political activities carried out by political parties contesting the election to win the sympathy of the majority voters, namely Muslims. The involvement of religious figures who have a clear mass base with high support militancy divides voters.

\section{Result and Discussion}

There are two forms of competition between Islamic political parties and nationalist political parties until the 2019 elections. These forms indicate a condition in which all parties do the same thing and fight for the sympathy of the same voters in an open and increasingly competitive manner. In principle, what the political parties done, both based on Islam and Pancasila (Gerinda; Pancasila and the 1945 Constitution), is a political medium to win the sympathy of voters, even though it leaves many problems among voters.

\subsection{Religious elite recruitment}

Apart from important figure among the people, elite or religious figures are also a reference in religious affairs. In this article, it does not list the elite or religious figures recruited into Islamic political parties because these parties already have strong roots in Islam. In the following, Table 1 (see. Appendix) shows the involvement of elites or religious leaders in nationalist political parties. Table 1 shows that in the nationalist parties, several Islamic figures are involved and have a reasonably good mass base. For instance, Gus Nabil studied at the Lirboyo, a famous Islamic Boarding School in East Java. At Lirboyo, he developed his 
career as a writer and a manager, and even an administrator of the Lirboyo Islamic Boarding School to become one of the Nahdlatul Ulama Executive Board. Meanwhile, Zainul Madji or Tuan Guru Bajang is an important figure in Nahdlatul Wathan (NW) which grew up in West Nusa Tenggara (NTB). He is a scholar who has broad insight and support in NTB. Likewise, KH Muhammad Ayyub Saifurrijal, Caretaker of As Siddiqi Islamic Boarding School Putri Jember, is a figure who is part of the Nasdem Party. He has a certain mass base because he is the caretaker of one of the Islamic boarding schools in this area. Like Masykur Ali and Gus Irfan, they have a robust cultural base in the pesantren.

The involvement of ulama in politics has a function other than influencing Muslim voters because of their capacity as Islamic figures and can minimize internal conflicts within political parties (Muazaroh \& Subaidi, 2019). This cannot be separated from the figures who have been the preference of Muslims, such as KH Maimoen Zubair at PPP. Ulama also has a solid mass base that makes easier mobilizing, including the ownership of Islamic boarding schools, which can be used as a basis for socializing the party's vision and being a basis for collecting votes (Sari, 2020). This condition encourages party elites to involve ulama in their party. In various conditions, it is not easy to assess the political behaviour of the people in Indonesia. This is because practices do not show the determination of choice in the vision or program of the political party he chooses, but rather on who is in the party.

\subsection{Establishment of political party religious institutions}

The establishment of party institutions carried Islam as an arena for contesting the votes. Islamic political parties culturally already have a base of Islamic voters. Meanwhile, nationalist political parties use these religious institutions to show that these parties are not anti-Islamic, thus, the majority of Muslim voters have "theological" reasons for choosing them. For example, there is Baitul Muslim Indonesia in PDI-P; Islamic Da'wah Council (MDI) and Al-Hidayah Study in Golkar; Greater Indonesia Muslim Movement in Gerindra; and SBY Nurussalam Dhikr Council in Demokrat.

One of the goals of the organization is to serve as a medium for the propagation of Islam. During the celebration of Islamic holidays, this organization becomes the "representative" of political parties in contact with the community, especially Muslims. Likewise, in Ramadan, organizations such as Bamusi perform tarawih tours to various mosques. There is also training for young preachers who will be deployed to the community as Islamic da'wah carriers.

"Bamusi's establishment is a form of Islamic symbols. Within PDIP itself, both central and regional administrators are predominantly Muslim, while the rest are from various

religions. Some PDPs identify with negative things to Bamusi becomes a means of reducing it all" (Interview, August 2021).

The role of religious party institution is to become a connecting between voters and the party (Freedman, 2020). In addition, the religious institutions of political parties are also a tool to approach them. Baitul Muslimin (BAMUSI), for example, is a PDI-P religious institution mandated to link parties with the community (Sutarto et al., 2019). Likewise, the SBY Darussalam Dhikr Council has become a propaganda medium for the Democratic Party. Its activities have been able to carry out da'wah's political function as part of the interest-group system.

The formation of wing organizations of political parties and the two things above have the same goal, namely trying to win the sympathy of voters. Apart from being an extension of political parties, wing organizations are also a medium for non-structural parties to participate in political parties, in this case, as a cadre of future party successors. This wing organization 
can be a direct link between political parties and voters' interests (Saifulloh, 2020). For instance, Gerindra shows that the wing organizations have good effectiveness in producing party successors (Furqan \& Hasan, 2019). One of the board members of the Gerindra wing, the Greater Indonesia Volunteer Unit (Satria), stated that:

"With the existence of wing organizations, although there are overlapping positions in the party, the change in recruitment policy was originally based on cadres to become an open party, especially in the recruitment of candidates, the role of the party wing is greatly reduced. But this happened in the nationalist party" (Interview, SQ, July 2021).

The role of the wing organization is not politically active. It is simply an extension of the party. For example, suppose there is a natural disaster. Various wing organization activities remain under the banner of the parent political party because these organizations are easy to get support, including funding (Bill, 2020).

The failures experienced by Islamic political parties in the 2019 elections varied. This failure can be seen, for example, related to the pragmatism of the party so that it is difficult to be consistent, the failure of regeneration, however, it only relies on specific figures at every era, even the absence of respected cultural figures/leaders, and the dualism of party management (Khasanah \& Hamzani, 2019). What happend to PKS, PPP, and PBB is a portrait of the complexity of the problems faced by Islamic political parties in Indonesia. The complexity of the problem can be seen when the internal conflict resolution mechanism fails at almost the same time as the failure of a "counterpart" party is established.

\section{Conclusion}

This article emphasizes that the contestation of Islamic and nationalist political parties continues in various aspects. The three forms of activity above are not only indicative of the strenuous efforts made by each political party to form a solid network to various sectors and levels but also an indicator of the activeness of all parties in establishing themselves as open and accommodating to Islam. Although there are labels as "religious" and "non-religious" parties, the label is not straightforward considered the distribution of religious elites, especially Islam (read: figures/ulama) in every political party. Moreover, it can be seen that all parties show a very accommodative attitude towards various social groups, especially religion. Meanwhile, there is also a blurring of non-linear political attitudes among voters who no longer vote based on party preferences but prefer figures.

\section{Acknowledgement}

This article results from a research that is supported through grant from the DPRM Dikti, 2021-2022.

\section{References}

[1] Al-Husainni, Y. D., \& Fuady, M. (2016). Strategi Komunikasi Politik Kader Muda Partai Gerindra. Prosiding Hubungan Masyarakat, 2 (1), 257-265. http://karyailmiah.unisba.ac.id/index.php/humas/article/view/2991/pdf. 
[2] Bezhan, F. (2017). Nationalism, Not Islam: The "Awaken Youth" Party and Pashtun Nationalism. In Green N. (Ed.), Afghanistan's Islam: From Conversion to the Taliban. California: University of California Press.

[3] Bill, S. (2020). Counter-Elite Populism and Civil Society in Poland: PiS's Strategies of Elite Replacement. East European Politics and Societies, 20 (10), 1-23. https://doi.org/10.1177/0888325420950800.

[4] Freedman, M. (2020). Vote with your rabbi: The electoral effects of religious $\begin{array}{lllll}\text { institutions in } \quad \text { Israel. Electoral } & \text { Studies, } & \text { 68, }\end{array}$ https://doi.org/10.1016/j.electstud.2020.102241

[5] Furqan, F., \& Hasan, E. (2019). Efektivitas Keberadaan Organisasi Sayap Partai Gerindra terhadap kaderisasi Politik Partai Gerindra Aceh. Jurnal Ilmiah Mahasiswa, 4 (2), 1-14. http://jim.unsyiah.ac.id/FISIP/article/view/11034/4634.

[6] Herdiansah, A. G. (2017). Pragmatisme partai Islam di Indonesia: pendekatan tindakan sosial. Sosioglobal: Jurnal Pemikiran dan Penelitian Sosiologi, 1 (2), 152-167. https://doi.org/10.24198/jsg.v1i2.13504.

[7] Kadir, A. G. (2014). Dinamika partai politik di Indonesia. Sosiohumaniora, 16 (2), 132-136. https://doi.org/10.24198/sosiohumaniora.v16i2.5724.

[8] Khasanah, N., \& Hamzani, A. I. (2019). Relasi agama dan demokrasi: telaah kritis eksistensi partai Islam di Indonesia. Salam: Jurnal Sosial dan Budaya Syar-I, 6 (4), 391-404. https://doi.org/10.15408/sjsbs.v6i4.13745.

[9] Muazaroh, S., \& Subaidi, S. (2019). Cultural capital dan kharisma kiai dalam wacana partai politik. SANGKéP: Jurnal Kajian Sosial Keagamaan, 2(2), 185-196. https://doi.org/10.20414/sangkep.v2i2.946.

[10] Mukminin, M. A., \& Sumarno. (2015). Hubungan NU dan Masyumi (1945-1960) konflik dan keluarnya NU Dari Masyumi. AVATARA: E-Journal Pendidikan Sejarah, 3 (3), 487-494.

https:/jurnalmahasiswa.unesa.ac.id/index.php/avatara/article/view/12808/11801.

[11] Nashir, H., Qodir, Z., Nurmandi, A., Jubba, H., \& Hidayati, M. (2019). Muhammadiyah's moderation stance in the 2019 general election. Al-Jami'ah, 57 (1), 1-24. https://doi.org/10.14421/ajis.2019.571.1-24.

[12] Nurdin, M. A., Saputra, A. T. D., \& Prayitno, A. (2019). Prahara partai Islam: komparasi konflik internal PPP dan PKS. Jakarta: Yayasan Pustaka Obor Indonesia.

[13] Nurhasim, Moch (ed.). (2016). Masa Depan Partai Islam di Indonesia: studi tentang Volatilitas Elektoral dan Faktor-faktor Penyebabnya. Yogyakarta: Pustaka PelajarLIPI.

[14] Qodir, Zuly., Hasse Jubba, Dyah Mutiarin, Mega Hidayati. (2021). Muhammadiyah Identity and Muslim Public Good: Muslim Practices in Java. International Journal of Islamic Thought, 19(1), 133-146. http://www.ukm.my/ijit/wpcontent/uploads/2021/05/IJIT-Vol-19-June-2021 14 133-146.pdf.

[15] Royyani, M. A., \& Takayasa, T. I. (2020). Ulama dā Politik: Relasi Politik Tuan Guru Bajang pada Pemilu 2019. JPW: Jurnal Politik Walisongo, 2 (1), 1-12. https://journal.walisongo.ac.id/index.php/JPW/article/view/2697.

[16] Saifulloh, P. P. A. (2020). Politik Hukum Pengaturan Organisasi Sayap Partai Politik dalam Hukum Positif Indonesia. Volksgeist: Jurnal Ilmu Hukum dan Konstitusi, 3 (2), 17-32. https://doi.org/10.24090/volksgeist.v3i2.3974.

[17] Sari, N. (2020). Kiyai dan Politik: Analisis Peran kiyai dalam Pilkada OKI 2018 Kecamatan SP Padang. Ampera: A Research Journal on Politics and Islamic Civilization, 1 (3), 208-225. https://doi.org/10.19109/ampera.v1i3.7428. 
[18] Sutarto, S., Lubis, S., \& Katimin, K. (2019). Political Imaging Techniques Carried Out by Baitul Muslimin Indonesia (BASUMI) in Increasing Public Political Support for PDI Perjuangan Medan City. Budapest International Research and Critics Institute$\begin{array}{llll}\text { Humanities and Social Sciences, } 2 & \text { (3), 164-174. }\end{array}$ https://doi.org/10.33258/birci.v2i3.403.

\section{Appendix}

Table 1. Religious Elite in Nationalist Political Party

\begin{tabular}{|c|c|c|}
\hline Political Party & Name & Position \\
\hline PDI-P & Gus Nabil Haroen & $\begin{array}{l}\text { Member of the Indonesian House of } \\
\text { Representatives from the PDI-P; Lirboyo Islamic } \\
\text { Boarding School alumni/managers }\end{array}$ \\
\hline GOLKAR & TGB Zainul Majdi & $\begin{array}{l}\text { Chairman of PB Nahdlatu Al-Wathan in } 1999 \text {; } \\
\text { Chairman of the Coordinator of the Community } \\
\text { Affairs of Golkar (Central Board) }\end{array}$ \\
\hline NASDEM & $\begin{array}{l}\text { KH Muhammad } \\
\text { Ayyub Saifurrijal }\end{array}$ & $\begin{array}{l}\text { Founder of the community organization NasDem; } \\
\text { Caretaker of As Siddiqi Islamic Boarding School } \\
\text { Putri Jember }\end{array}$ \\
\hline DEMOKRAT & Masykur Ali & $\begin{array}{l}\text { Democratic Cadre; The caretaker of the Ibn Sina } \\
\text { Islamic Boarding School, Tile, Banyuwangi }\end{array}$ \\
\hline GERINDRA & $\begin{array}{l}\text { M Irfan Yusuf Hasyim } \\
\text { (Gus Irfan) }\end{array}$ & Vice-chairman of Lembaga Ekonomi NU \\
\hline
\end{tabular}

Source: Processed from various documents 